3. Discography by Paul Moria Orchestra. Retrieved from: www / paulmauriat. ru/cd_1965.htm

4. Martynov V. (1974) Time and Space as Factors of Musical Formation. Rhythm, Space and Time in Literature and Art. L., 1974, P. 238-247 [in Russian].

5. Syrov V. Shlyager and a masterpiece (to the question of the annihilation of concepts). The art of the twentieth century: the elite and the masses. N. Novgorod, 2004. P. 280-288 [in Russian].

6. Les Swingle Singers Discography. Retrieved from: www / discogs / com | artist | 339330-Les-Swingle-Singers

7. Vanessa-Mae Discography. Retrieved from: www.discogs.com/artist/24218-Vanessa-Mae

Стаття надійшла до редакиії 20.09.2017

УДК $78.03+786.2$

DOI: 10.31723/2524-0447-2017-25-185-202

\author{
Екатерина Ивановна Ергиева \\ https://orcid.org/0000-0001-9710-7557 \\ преподаватель кафедры специального фортепиано \\ Одесской национальной музыкальной академии \\ им. А. В. Неждановой \\ violenion@gmail.com
}

\title{
К ПРОБЛЕМЕ ХУДОЖЕСТВЕННОЙ ЦЕЛОСТНОСТИ МУЗЫКАЛЬНОГО ПРОИЗВЕДЕНИЯ КАК ПРОЯВЛЕНИЯ ХОЛИСТИЧНОСТИ ЛИЧНОСТИ ПИАНИСТА
}

Цель статьи - рассмотреть феномен холистичности личности пианиста как предпосылку художественной иелостности музыкального произведения. Методология исследования имеет интердисциплинарный характер и заключается в использовании, наряду с музыковедческими, также и холистических подходов в анализе музыкального искусства. Такая методология позволяет выявить ту иелостность личности, те ее характеристики, которые в значительной мере определяют как иенностные показатели отдельных продуктов духовной деятельности музыканта-художника, так и эпохальность всего наследия твориа в его универсальном проявлении - композиторстве-исполнительстве, а последнее, в свою очередь, оказывает глобальное воздействие на всю мировую человеческую культуру. Научная новизна: впервые в украинском музыкознании применение холистических методов анализа музыкального искусства позволяет устанавливать причинно-следственную связь в процессе создания музыкально-художественной целостности. Выводы: источником творческой самобытности музыканта является его лич-

(С) Ергиева Е. И., 2017 
ность, мировоззрение, его субъективный опыт впечатлений, переживаний. Лишь проявление своей индивидуальности, холистичности становится предпосылкой «нового слова» в искусстве. Примером подобной реализации холистичной личности является универсальное творчество С. Прокофьева, который совмещал композиторскую и исполнительскую деятельность. Изучение личности С. Прокофьева с позиций холизма позволяет обосновать гуманистическую направленность и духовную цельность творчества С. Прокофьева, четко выраженную последовательность в развитии художественного стиля композитора, обосновать как художественную целостность его исполнительских интерпретаций, так и метафизическую целостность всего наследия композитора.

Ключевые слова: авторское исполнение, авторско-исполнительская синергия, метафизичность творчества, холистичность, художественное творчество, целостность.

Yerhiieva Kateryna, lecturer of department of special piano, Odessa $\mathrm{Na}$ tional A. V. Nezhdanova Academy of Music

To the problem of artistic integrity of a musical work as a demonstration of holism of pianist's personality

Article purpose - to consider the phenomenon of holism of musician's personality as a prerequisite for artistic integrity of a musical work. Methodology of research has an interdisciplinary character and consists in using, along with musicological, also holistic approaches in the analysis of musical art. This methodology allows to identify the integrity of the personality, those of its characteristics, which largely determine both the value indicators of individual products of musician-artist's spiritual activity, and the epochal significance of whole creator's heritage in its universal manifestation - composing-performing, and the last, in its turn, has a global impact on the entire world human culture. Scientific novelty: for the first time in Ukrainian musicology, the use of holistic methods of analyzing the musical art allows to define a cause-and-effect relationship in the process of creating a musical and artistic integrity. Conclusions: the source of the creative identity of the musician is his own personality, his world view, his personal experience and impressions. Only the manifestation of one's individuality, holistic integrity, becomes the prerequisite for a «new word» in art. An example of such a realization of a holistic personality is the universal creativity of S. Prokofiev, who combined compositional and performing activities. Studying the personality of $S$. Prokofiev from the standpoint of holism allows to substantiate the humanistic orientation and spiritual integrity of S. Prokofiev's creativity, well-defined sequence in the development of the composer's artistic style, to substantiate both the artistic integrity of his performing interpretations and the metaphysical integrity of the composer's entire heritage.

Keywords: author's performance, authorial-performing synergy, metaphysics of creativity, holism, artistic creativity, integrity. 
Сргієва Катерина Іванівна, викладач кафедри спеціального фортепіано Одеської національної музичної академії імені А. В. Нежданової

До проблеми художньої цілісності музичного твору як прояву холістичності особистості піаніста

Мета статті - розглянути феномен холістичності особистості пiаніста як передумову художньої цілісності музичного твору. Методологія дослідження має інтердисциплінарний характер і полягає в використанні, поряд з музикознавчими, також і холістичних підходів в аналізі музичного мистецтва. Така методологія дозволяє виявити ту цілісність особистості, ті їі характеристики, які в значній мірі визначають як ціннісні показники окремих продуктів духовної діяльності музиканта-художника, так і епохальність всієї спадщини твория в його універсальному прояві - композиторстві-виконавстві, а останне, в свою чергу, справляє глобальний вплив на всю світову людську культуру. Наукова новизна: вперше в українському музикознавстві застосування холістичних методів аналізу музичного мистецтва дозволяє встановлювати причинно-наслідковий зв'язок в процесі створення музично-художньої цілісності. Висновки: джерелом творчої самобутності музиканта є його особистість, світогляд, його суб'єктивний досвід вражень, переживань. Лише прояв своєї індивідуальності, холістичності стає передумовою «нового слова» в мистецтві. Прикладом подібної реалізації холістичної особистості є універсальна творчість С. Прокоф'єва, який поєднував композиторську і виконавську діяльність. Вивчення особистості С. Прокоф'єва з позицій холізму дозволяє обгрунтувати гуманістичну спрямованість і духовну цілісність творчості С. Прокоф'єва, чітко виражену послідовність у розвитку художнього стилю композитора, обгрунтувати як художню цілісність його виконавських інтерпретацій, так і метафізичну цілісність всієї спадщини композитора.

Ключові слова: авторське виконання, авторсько-виконавська синергія, метафізичність творчості, холістичність, художня творчість, иілісність.

Актуальность исследования. В современном культурном пространстве личностные качества музыканта, его холистичность, выражение личностного смысла действительности вызывают больший интерес, нежели способы, которые используются артистом для выражения своей индивидуальности. В связи с этим актуальным становится исследование творчества музыкантов-универсалов, сочетающих композиторскую и исполнительскую деятельность. Примером подобной холистичной личностной самореализации является фортепианное творчество С. Прокофьева. Помимо этого в современном искусствоведении существует необходимость переосмысления места и роли С. Прокофьева в мировом культурном пространстве, потребность в 
более глубоком изучении его творчества с современных научных позиций, которые радикально отличаются от однозначного социальноидеологического подхода к изучению его наследия в прошлом.

Научная новизна: впервые в украинском музыкознании применение холистических методов анализа музыкального искусства позволяет устанавливать причинно-следственную связь в процессе создания музыкально-художественной целостности. В статье апробированы холистические подходы в анализе музыкального искусства. С помощью этой методологии возможно выявить ту целостность личности, те ее характеристики, которые в значительной мере определяют как ценностные показатели отдельных продуктов духовной деятельности музыканта-художника, так и эпохальность всего наследия творца в его универсальном проявлении - композиторстве-исполнительстве, а последнее, в свою очередь, оказывает глобальное воздействие на всю мировую человеческую культуру.

Цель статьи - рассмотреть феномен холистичности личности музыканта как предпосылку художественной целостности музыкального произведения. Объект исследования - феномен холистической личности композитора-исполнителя. Предмет исследования - художественная целостность фортепианных произведений С. Прокофьева.

Анализ исследований и публикаций. Думается, что традиционный музыковедчески-текстологический подход к анализу произведений С. Прокофьева, выявляющий и рассматривающий их смысл только лишь как непосредственный ответ на животрепещущие события современной композитору эпохи, не вполне позволяет обнаружить подлинную их сущность, которая намного глубже.

Уместными здесь, на наш взгляд, могут быть семантические, интердисциплинарные подходы, характерные для современного музыкознания с его «экстравертной» (И. Котляревский) направленностью, позволяющие «избежать упрощающих образные значения музыки прямолинейных музыковедческих определений», уходя «...от композиционных границ музыкального произведения - к ноэтической поэтике культуры в целом - с последующим возвращением к смысловым структурам музыки, но, скорее, не констатирующим, а прогностическим - «угадывающим» их будущие возможности...» $[17,25]$.

К примеру, Аиси, придерживаясь подобной методологии, рассматривает феномен концертности как стилевую парадигму фортепианного творчества С. Прокофьева, Д. Андросова обнаруживает футуристические показатели выразительности в первых фортепианных 
Сонатах композитора, а Т. Сафонова - метафизическую составляющую всего творчества С. Прокофьева.

В исследовании личности композитора такого масштаба как С. Прокофьев, содержания его композиторского и исполнительского наследия, безусловно необходим и феноменологический метод.

Базовыми философскими установками здесь могут быть феноменология Э. Гуссерля и феноменологическая герменевтика П. Рикера.

Основное изложение материала. Как известно, творчество - это деятельность человека, направленная на созидание, воплощение каких-либо новых идей в виде культурных ценностей. Это процесс (к примеру, композиторское творчество), реализующий «возникшую в труде способность человека из доставляемого действительностью материала (на основе познания закономерностей объективного мира) создавать новую реальность, удовлетворяющую многообразие общественной потребности» (курсив наш) [16, с. 405].

С этой дефиницией творчества резонирует философская концепция холизма. «Холизм (греч. holos - целое) - идеалистическая философия целостности <...> Это понятие введено <...> Я. Смэтсом в книге «Холизм и эволюция» (1926). Идеалистически истолковывая несводимость целого и суммы частей, Смэтс утверждает, что миром правит холистический процесс - процесс творческой эволюции, создания новых целостностей» (курсив наш. - E. E.) [16, с. 449].

Итак, холизм концептуально рассматривает «мир как результат творческой эволюции, направляемой нематериальным «фактором целостности» < ...> Весь мир с точки зрения холизма - это единое целое, а выделяемые нами отдельные явления и объекты имеют смысл только как часть общности <...> Пример холистического утверждения из трудов Гиппократа: «человек есть универсальная и единая часть от окружающего мира», или же «микрокосм в макрокосме»» [1].

$\mathrm{C}$ позиций холизма мы будем анализировать и фортепианное творчество С. Прокофьева, эпохальность которого обеспечила культурную эволюцию человечества, оказала «дальнобойное» воздействие на рождение новых жанрово-стилистических музыкальных явлений в XX и XXI веках, в том числе и рок-музыки (к примеру, Седьмая соната композитора).

Сам С. Прокофьев неоднократно превозносил «радость творческого труда», преследующего цель - «благо народа», воспевал в своем творчестве «красоту человека» в единстве с «богатством природы» («Сказ о каменном цветке» по П. Бажову» [23, 130-131]. 
Таким образом, холистичность его личности нашла свое отражение в целевых установках самого композитора.

Творчество специфично для человека, оно всегда «предполагает творца - субъекта творческой деятельности» [22, 476].

Поэтому художественное творчество в широком смысле означает создание качественно нового духовного продукта в различных областях культуры (культурные ценности, к примеру, музыкальные композиции) и предполагает холистичность самой личности музыканта, проявляющуюся в различных формах самости, таких как: рефлексия, самоактуализация, самораскрытие, самопознание, самопрезентация, самовыражение, самореализация и др.

Формы самости («Я»-проявления) в музыкально-исполнительской деятельности - вторично-продуктивной по отношению к авторской, проявляются прежде всего в исполнении музыкального произведения («вторично творчески-созидательном становлении музыкальной образности» по В. Москаленко), на которое накладывает отпечаток темперамент, мысли, чувства каждого исполнителяличности и которое реализуется в конечном итоге в «произведении исполнителя» [14, 12].

По мнению выдающегося психолога А. Мелик-Пашаева, помимо эмпирического «Я», или повседневного самосознания, существует также высшее «Я». В нем заключены все те возможности, которые в перспективе могут быть раскрыты человеком. При этом они ограничены пространственно-временными рамками и той социокультурной средой, в которой он живет.

Понятие высшего «Я» в психологии носит универсальный характер. Оно проявляется в процессе духовного развития личности в человеческой деятельности и самосознании. Этот процесс в идеале должен быть основой для любых творческих проявлений человека. Поэтому одним из синонимов высшего «Я» может быть творческое «Я».

Важную роль в активизации потребности реализации своего творческого «Я» - как основной движущей силы духовного развития играет психологический феномен, называемый А. Мелик-Пашаевым «встречами с собой». Иными словами, происходит как бы «прорыв» высшего «Я» в повседневное сознание человека, благодаря чему он может узнать свои истинные возможности, а иногда и направление своего дальнейшего творчества.

Об этом феномене говорили многие выдающиеся исполнителиартисты. Так, английский актер и режиссер Э. Крэг описывает его 
как «сокровенные глубины личности, в которых таится нечто, что актер должен в себе изучать» $[10,193]$.

Е. Гротовский рассматривал этот феномен актера как «зерно своего существа», обозначая его также как «внутреннее бытие», «бытиенутро» $[4,71]$.

«Слушайте музыку вашей душой, - напутствовала Айседора Дункан своих учениц, - а слушая, разве вы не чувствуете пробуждающееся глубоко внутри вас ваше внутреннее «Я»? Не его ли силою у вас поднимается голова, взметываются кверху руки, не его ли силою вы медленно шагаете навстречу свету?» [11, 114].

В лучшие моменты исполнения, когда артист на сцене чувствует прилив истинного вдохновения, озарения, он открывает в своей игре самые сокровенные глубины своей личности, как бы «исповедуется» перед слушателями. Именно это придает концертному публичному исполнительству ту вечную притягательность, которая принуждает людей и в эпоху internet-пространства посещать концерты, не замыкаясь в виртуальной действительности с прослушиванием музыки только в аудио- и видео- записях, пусть даже самого высокого качества.

Творческое «Я» музыканта - это и есть показатель его холистичности, то есть той цельности, которая больше чем «integritas» в средневековом смысле (пусть даже по принципу калогатии), и даже суммарной совокупности его способностей, свойств личности и профессиональных качеств (музыкального слуха, чувства ритма, отзывчивости на музыку, интеллектуализма, качеств памяти, виртуозности, мн. др.).

Холистичность ведет личность музыканта по выбранному им курсу к неординарным творческим проявлениям, к высоким целям, к Парнасу музыкального искусства. Она зиждется на подспудном ощущении необычайной внутренней духовной силы, активности, пассионарности, проявляет себя во внутреннем импульсе к неуемной творческой деятельности, непреодолимом желании совершить что-либо по-своему, по-новому, направляет перо писателя, кисть художника, создает высочайшее качество игры на музыкальном инструменте, определяет способ высказывания и придает ему убедительность и яркость.

Творческие способности - это не набор различных качеств, каждое из которых существует само по себе. Наоборот: отдельные способности проявляются и становятся творческими благодаря холистичности личности с ее особым взглядом на мир. Следовательно, способно- 
сти - это не отдельный элемент психики, а особое ее «состояние», измененное тем мировоззрением и отношением к самому себе, которое закладывает основу для реализации «творческого Я».

А. Мелик-Пашаев характеризует такое отношение к действительности как «эстетическую позицию» или «эстетическое отношение». Оно возникает на основе тех или иных важных впечатлений и переживаний, которые не всегда встречаются в обыденной жизни (в конкретных поступках либо в эмоциональных реакциях), но становятся источником создания альтернативной действительности в форме художественных произведений.

Способности к художественному творчеству холистичной личности музыканта посредством «эстетического отношения» К действительности проявляются необычайно ярко. При этом артист не только воплощает в субъективных формах многогранность и ценность окружающего мира, но и утверждает свое собственное творческое «Я», свой уникальный взгляд на этот мир.

Мотивирующая сила эстетического отношения в том, что художественное творчество является одним из способов приблизиться к своему истинному духовному «Я» и максимально реализовать его в эмпирической действительности.

Из высказываний известного русского философа Н. Бердяева следует, что «реальная глубина духа познается экзистенциально в переживании судьбы, в страдании, тоске, смерти, любви, творчестве, в свободе» [2, 389].

Воистину «подобное познается подобным» [9, 63]. Богатство личного жизненного опыта обеспечивает многогранное обнаружение образного содержания в композиторском тексте, с одной стороны, и модальное наполнение исполнительского произведения - с другой.

Через расширение эстетического опыта и реализацию его в художественных произведениях человек достигает единения с окружающим его миром. Важнейшая черта эстетического отношения заключается в особой восприимчивости художника к действительности. Такое восприятие не ограничивается внешней материальной стороной и констатацией различных вещей, явлений, но отличается оценкой объектов как выразительных образов, отображающих внутреннее состояние, настроение, судьбу - ту родственную человеку внутреннюю жизнь, которую это отношение находит во всех явлениях бытия. 
«Публика заражается только тем, чем живет артист, и не только в данную минуту на сцене, но и тем, что любит его душа, чему он поклоняется или просто любит инстинктивно, тем, что он есть в своем главном, сокровенном существе» - писал Л. А. Сулержицкий [20, 505].

Таким образом, источником самостоятельности исполнителя, его самости является его личность и те субъективные впечатления, переживания, мысли, идеи, которые он испытал в своей жизни. Каждый человек имеет уникальный внутренний мир. Следовательно: лишь проявление своей индивидуальности, холистичности становятся предпосылкой «нового слова» в искусстве.

Само собой разумеется, что художественные новации не рождаются безынициативной личностью.

По словам известного писателя С. Моэма, «самое интересное в искусстве - личность художника» [15].

Поэтому все духовные усилия музыканта в процессе его обучения направлены на формирование самостоятельного, художественного характера, своей индивидуальности.

Индивидуальность исполнителя связана не только с определенным комплексом способностей, не только с темпераментом и воображением. Она формируется на основе жизненного и душевного опыта, социальных связей, мировоззрения артиста (его «образа мира»).

Холистичность исполнителя обусловливает убедительность его сценической игры как артистическое единство переживаний души, адекватных телесных перевоплощений и духовности, которое отражается в так называемой исполнительской синергии (по И. Ергиеву единстве потоков сознания, движения и звучания).

Кроме того, уровень профессионализма музыканта тесно связан со степенью пластичности, мобильности его личности, способностью к перевоплощению, быстрому переключению в различные характеры и настроения, составляющие содержание музыкального произведения.

Личностное начало - это собственный, неповторимый взгляд на мир, на искусство и на самого себя. О его значимости для артиста говорили такие выдающиеся театральные деятели, как К. Станиславский и Б. Брехт, несмотря на то, что их взгляды на театральное искусство во многом противоположны.

«Никогда не теряйте себя самого на сцене, - нередко повторял K. Станиславский, - всегда действуйте от своего лица человека-ар- 
тиста. От себя никуда не уйдешь. Если же отречься от своего я, то потеряешь почву, а это самое страшное» [19, 242].

«Если исполнитель не проявляет в роли своей человеческой природы, его создание мертво» [19, 355].

Б. Брехт предостерегал артистов от зеркального, механического отражения окружающего мира. Только субъективно трасформированное бытие в соответствии с «образом мира» (А. Сокол) артиста может стать основой для высокохудожественного творчества.

Выразительность и глубина звучания музыки, художественное содержание «исполнительского произведения» (И. Ергиев) понятны публике только тогда, когда они осмыслены самим музыкантом-интерпретатором. Для этого, помимо технического совершенства исполнения, необходимо духовное богатство, харизматичность творческой личности исполнителя.

Внутренняя жизнь артиста, его философские взгляды, система нравственных и культурных ценностей, его взаимоотношения с другими людьми выступают своеобразной надстройкой над комплексом «артистической одаренности» (термин И. Ергиева) музыканта, являются основным источником творчества на сцене.

В таком случае музыкальное произведение «другого автора» выступает в качестве материала для раскрытия, самореализации творческой индивидуальности исполнителя, его холистичности.

Как отмечает А. Маслоу: «Трудно что-либо противопоставить холизму как основе научного мировоззрения, его полномочия очевидны, а истинность не вызывает сомнений,- в конце концов, космос един и внутренне взаимосвязан, всякое общество едино и внутренне взаимосвязано, всякий человек един и внутренне взаимосвязан и т. д., - однако же, холистичный подход пока почти не находит применения в науке, он до сих пор не используется в том качестве, в котором должен был бы использоваться, а именно как способ мировоззрения» (курсив наш. - E. E.) [12].

П. Гуревич подчеркивает, что «современная философия исходит из того, что сознание человека каким-то необъяснимым пока образом содержит информацию о всей Вселенной» [5, 136].

Однако целостность в духовно-личностном смысле не задана человеку, но обретается им. Это подтверждает П. Гуревич, который считает, что «целостность - это не данность, которая заложена в самой человеческой природе. Она не что иное, как мучительное обретение гештальта, некоей завершенности, относительной гармонии. Чело- 
век - это усилие быть человеком» (курсив здесь и далее наш. $-E$. $E$.) $[5,146]$.

Развивая эту идею, П. Гуревич резюмирует: «Цлостность свойственна человеку только как беспредельная возможность, как некая глубинная потребность <...> Но в ней обнаруживаются трагические и драматические констатации. Человеческая целостность существует лишь как устремление, как поиск, как напряжение «специфически человеческого» [5, с. 148].

Цель и смысл человеческого существования как творческой экзистенции конкретизирует Э. Фромм - «стать счастливым благодаря полной реализации дара, представляющего собой человеческую особенность - дара разума, любви, труда на благо человека и во имя человека» [21, с. 67-68].

В качестве примера подобной реализации холистичной личности можно привести выдающихся музыкантов, которые совмещали композиторскую и исполнительскую деятельность. История музыки представлена подобными гениями в изобилии: выдающиеся пианисты В. А. Моцарт, Л. ван Бетховен, Ф. Лист, Ф. Шопен, С. Рахманинов, А. Скрябин; скрипачи-виртуозы: Н. Паганини, Г. Венявский, А. Вьетан, Ф. Крейслер, замечательные дирижеры Р. Штраус, Р. Вагнер, Г. Малер. В этом ряду стоит и гениальный композитор и пианист Сергей Прокофьев.

Актуальным в творчестве вышеприведенных творцов становится авторское исполнение, которое объединяет в одно целое: содержание и форму, мысль, художественный образ и средства его воплощения, когда все согласованно, все гармонично, все живет неподдельной жизнью живого организма. В этом случае допустимо введение понятия авторско-исполнительской синергии, которое в своей сущности тесно переплетается с положениями холизма.

Примером авторско-исполнительской синергии могут служить исполнения-«прочтения» самого С. Прокофьева, доступные нашим современникам в аудиозаписях (к примеру, его концерт для фортепиано и симфонического оркестра № 3).

Личность гениального художника всегда вызывает интерес своей самобытностью, загадочностью и глубиной. Именно таким был выдающийся композитор XX в. Сергей Сергеевич Прокофьев. Об исполнительской стороне его творчества наиболее емко высказывался знаменитый пианист и педагог Г. Нейгауз: «Особенности Прокофьева-пианиста настолько обусловлены особенностями 
Прокофьева-композитора, что почти невозможно говорить о них вне связи с его фортепианным творчеством. Игру его характеризуют <..> мужественность, уверенность, несокрушимая воля, железный ритм, огромная сила звука <..> особенная «эпичность», тщательно избегающая всего слишком утонченного или интимного <...> Но при этом удивительное умение полностью донести до слушателя лирику <..>> грусть, раздумье, какую-то особенную человеческую теплоту, чувство природы - все то, чем так богаты его произведения» [23, 443].

М. Ростропович в своих высказываниях подчеркивал органическую взаимосвязь «ярко человеческой сущности Сергея Сергеевича» с его творчеством, а также «сходство между его походкой - подтянутой, ритмичной, прямой - и его музыкой» [23, 479].

Таким образом, целостность-холистичность личности Прокофьева отражена в высказываниях его выдающихся современников. В искусствоведении последних десятилетий наметилась необходимость переосмысления места и роли С. Прокофьева в мировом художественном процессе, а также более глубокого и адекватного понимания его творчества. Это вызвано, в первую очередь, отходом от однозначного социально-идеологического подхода к трактовке творчества композитора, который сформировался в советское время.

Особый интерес как сегмент содержания в метафизическом смысле вызывает присущее музыке С. Прокофьева «светлое начало» (в некотором смысле - проявление его неиссякаемого оптимизма). На фоне пессимизма, трагизма и безысходности мироощущения подавляющей части европейских композиторов первой половины XX века светлая, жизнеутверждающая музыка С. Прокофьева была удивительным явлением, неиссякаемым источником «живой» воды, дарующим слушателям чистоту и свет.

«Музыка у него всегда порождается бьющей через край радостью бытия: определение, которое Тагор применял к Моцарту, справедливо по отношению и к Прокофьеву», - пишет Ж. Брюир о С. Прокофьеве $[3,173]$. Не случайно Л. Гаккель назвал статью, посвященную С. Прокофьеву, «Он сам дитя», и пишет о нем как о гении, обладающем «детской конституцией» (выражение П. Флоренского), которая определила способность композитора не к эгоцентричному, но к объективно-целостному восприятию мира, «целостному психологическому резонансу человека с миром» $[17,24]$, что в свою очередь служит одним из подтверждений холистичности его личности. То, что 
музыке С. Прокофьева присуща светлая, оптимистическая направленность - общепризнанный факт. Однако однозначно определить природу и характер этого света не так просто, особенно учитывая то, что музыка композитора часто насыщена драматизмом, а порой и трагизмом.

Верное понимание смысла музыкального произведения, его семантической нагрузки возможно только через осознание «надсмысла» всего творчества композитора, через исследование его мировоззрения и глубинных слоев его личности. В связи с этим в контексте проблемы холистичности, поставленной в нашей статье, отдельные произведения С. Прокофьева и его творчество в целом рассматриваются нами с позиций раскрытия в них особенностей мировосприятия композитора.

Именно таковыми являются оптимизм, светлое начало в его музыке. В них внутреннее «Я» композитора является носителем архетипов национального сознания, русской истории и культуры, национальной духовной традиции с ее верой в возможность духовного преобразования мира.

В образном содержании музыки С. Прокофьева четко прослеживается его устремленность к вечности. В этом смысле особенно актуальна статья «Слово о Прокофьеве» А. Шнитке, по мнению которого, природа и характер оптимизма С. Прокофьева основаны на глубинных, внутренних основаниях его личности, которые он осознанно «защищал» от посторонних глаз.

Автор отмечает, что для композитора характерно «преодоление настоящего ради вечности» [8]. Даже в самых радостных, светлых эпизодах произведений С. Прокофьева явно чувствуется своеобразная «нехватка иного бытия» - трудно выразимое предощущение того, что невозможно пережить в реальном мире. В этих отзвуках иного бытия, в ощущении фантастичности, сказочности происходящего и раскрывается глубинный смысл его творений.

В качестве примера можно привести 3-й концерт для фортепиано, наполненный фантастическими звучаниями и образами, для которых сам автор в своем исполнении находит тончайшие краски. Как в самом концерте, так и в его интерпретации композитором выражены смысловые коннотации, не обусловленные какими-либо конкретными социальными, историческими событиями, и являющиеся проявлением наиболее скрытых, интимных сторон внутреннего мира художника. 
Так, ярким выражением прекрасной, но недостижимой в реальности мечты звучит наполненная проникновенным лиризмом тема центрального раздела финала концерта:

\section{С. Прокофьев, концерт № 3 (III ч.)}
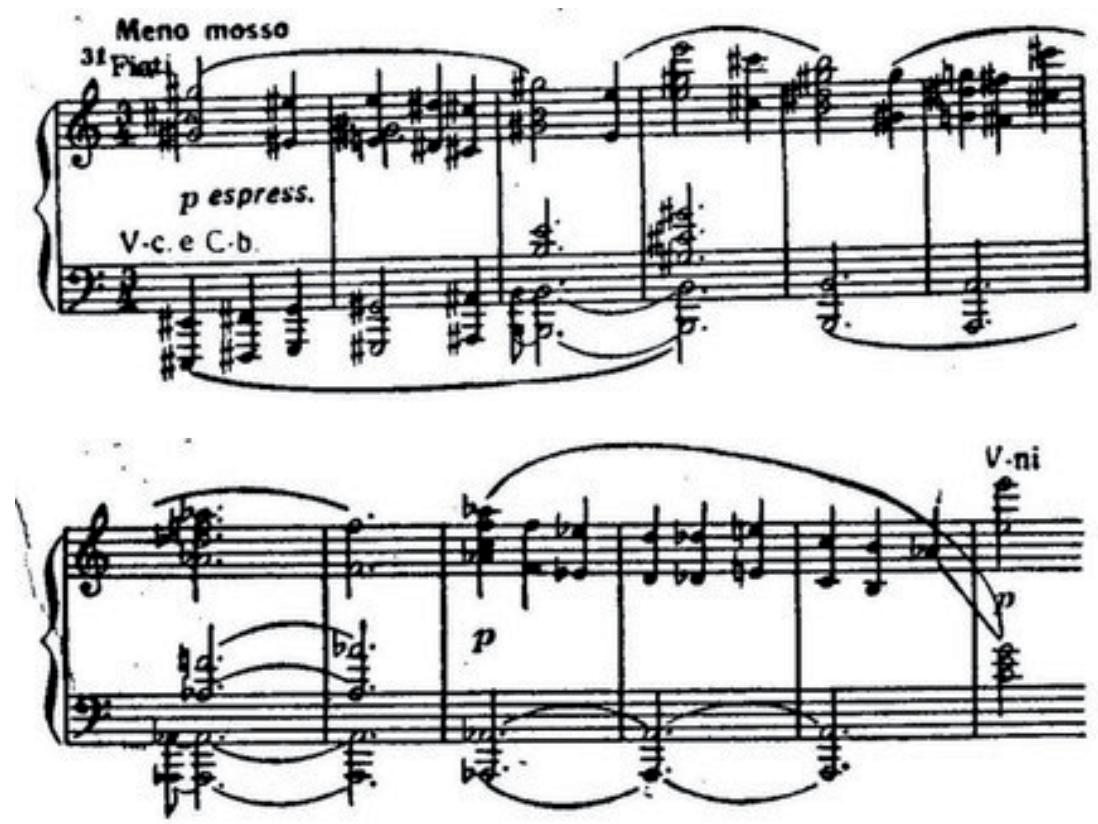

Контрастно по отношению к этой теме звучит следующий за ней сольный эпизод у фортепиано - тема угловатая, неуклюжая. После полнозвучия tutti у оркестра она звучит очень одиноко, будто это высказывание не понятой никем, на фоне общего ликования, души. Образ наполнен психологизмом и чем-то сходен с «Петрушкой» Стравинского - непривлекательный внешне, но глубокий внутри.

Исходя из этого, образ «успешного рационалиста со стальными бицепсами и трицепсами», навязанный С. Прокофьеву, существенно обедняет его музыку. Отсюда возникает необходимость обращения к глубинным пластам внутреннего мира художника, реконструкции его мироощущения, выяснения природы и истоков его оптимизма. Достигнуть этого можно, внимательно вслушиваясь в его музыку, постигая ее эйдетическую сущность. В музыке С. Прокофьева обнару- 
живается безотчетная вера в возможность духовного преображения мира, отрицание трагизма окружающей повседневной реальности и уход от нее в мир сказочный, фантастический.

\section{С. Прокофьев, концерт № 3 (III ч.)}

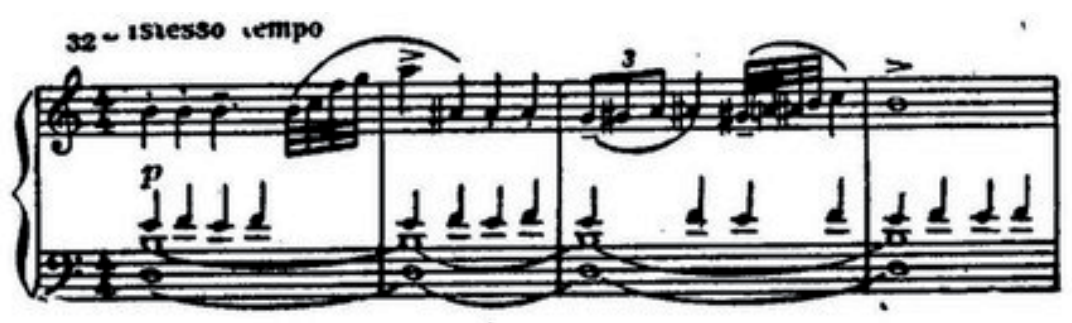

Выводы. Для творчества С. Прокофьева характерны противоречивые, иногда парадоксальные сочетания, такие как: бунтарство, новаторство - и приверженность классическим основам; рациональная ясность - и погружение в область иррационального; жизнерадостность - и «уход» от реальности в другой, фантастический мир. Эти оппозиции - проявление мироощущения художника, оптимизм которого основан на глубинной, бессознательной связи с русской ментальностью, с национальными культурными традициями русского народа.

Влияние этих базовых факторов является тем более существенным, что в своем творчестве С. Прокофьев сознательно отдалился от социальных перипетий, создав свой собственный, уникальный внутренний художественный мир. Только в нем композитор мог проявить свое подлинное творческое «Я».

Изучение личности С. Прокофьева с позиций холизма позволяет обосновать гуманистическую направленность и духовную цельность творчества Прокофьева, четко выраженную последовательность в развитии художественного стиля композитора.

Исследование холистичности личности С. Прокофьева, его мировоззрения, выявление в ней демиургического начала позволили сделать вывод не только о художественной целостности его интерпретаций как пианиста, но и о метафизической целостности всего наследия композитора - Человека-творца. 


\section{СПИСОК ЛИТЕРАТУРЫ}

1. Арт-психология для детей. Холистический подход [Электронный ресурс]. Режим доступа: http://kids-care.ru/index/kholistichesk4ij/0-48.

2. Бердяев Н. А. Философия свободного духа. М.: Республика, 1994. $480 \mathrm{c}$.

3. Брюир Ж. Очерк о Прокофьеве. Сергей Прокофьев. 1891-1991. Дневники, письма, беседы, воспоминания. М.: Советский композитор, 1991. С. 165177.

4. Гротовский Е. «Театр и ритуал». Театральная жизнь. 1988. № 10.

5. Гуревич П. С. Проблема целостности человека. М., 2004. 178 с.

6. Данько Л. Г. С. С. Прокофьев: популярная монография. 2-е изд., испр. Л.: Музыка, 1983. 96 с.

7. Ергиев И. Д. Артистизм музыканта-инструменталиста: монография. Одесса: Астропринт, 2014. 284 с.

8. Ивашкин А. В. Беседы с Альфредом Шнитке. М.: РИК «Культура», 1994. $304 \mathrm{c}$.

9. Кьеркегор С. Заключительное ненаучное послесловие к «Философским крохам» / пер. с дат. Н. Исаевой, С. Исаева. М.: Академический Проект, 2012. $607 \mathrm{c}$.

10. Крэг Э. Г. Воспоминания, статьи, письма. М.: Искусство, 1998. 376 с.

11. Курт П. Айседора. Неистовый танец жизни. М.: Эксмо, 2002. 768c.

12. Маслоу А. Мотивация и личность [Электронный ресурс]. СПб.: Евразия, 1999. Режим доступа: http://psylib.org.ua/books/masla01/txt00.htm.

13. Мелик-Пашаев А. А. Об источнике способности человека к художественному творчеству. Вопросы психологии. 1998. № 1. С. 76-82.

14. Москаленко В. Г. Лекции по музыкальной интерпретации: учеб. пособ. К., 2012. 272 c.

15. Моэм С. Луна и грош [Электронный ресурс]. М.: Правда, 1982. 431 c. Режим доступа: http://www.lib.ru/INPROZ/MOEM/moon.txt_with-bigpictures.html.

16. Розенталь М. М. Философский словарь. М.: Изд-во полит. лит., 1972. $496 \mathrm{c}$.

17. Самойленко А. И. Духовность как категория музыкальной семантики. Музичне мистецтво і культура: науковий вісник Одеської державної музичної академії імені А. В. Нежданової / [гол. ред. О. В. Сокол]. Одеса: Друкарський дім, 2009. Вип. 10. С. 18-27.

18. Сокол А. В. Исполнительские ремарки, образ мира и музыкальный стиль. Одесса: Моряк, 2007. 276 с.

19. Станиславский К. С. Работа актера над собой. М.: Искусство, 1981. $668 \mathrm{c}$.

20. Сулержицкий Л. А. Повести и рассказы. Статьи и заметки о театре. Переписка. М.: Искусство, 1970. 707 с.

21. Фромм Э. Человек для себя. М.: АСТ; Мн.: Харвест, 2006. 352 с. 
22. Хоруженко К. М. Культурология: энциклопедический словарь. Ростов н/Д.: Феникс, 1997. 640 с.

23. Шлифштейн С. И. С. С. Прокофьев: материалы, документы, воспоминания. Изд. 2-е, доп. М. : Гос. муз. изд-во, 1961. 707 с.

\section{REFERENCES}

1. Art-psychology for children. Holistic approach. Retrieved from http://kidscare.ru/index/kholistichesk4ij/0-48 [in Russian].

2. Berdyaev, N. (1994). Philosophy of the free spirit. Moscow: Republic [in Russian].

3. Breuer, J. (1991). Sketch about Prokofiev. Sergei Prokofiev. 1891-1991. Diaries, letters, conversations, memories. Moscow: Soviet Composer [in Russian].

4. Grotowski, J. (1988). Theatre and ritual. Theatrical Life no. 10 [in Russian].

5. Gurevich P. The problem of human integrity. Moscow [in Russian].

6. Danko, L. (1983). S. S. Prokofiev: popular monography. Leningrad: Music [in Russian].

7. Yergiyev, I. (2014). Artistism of musician-instrumentalist. Monography. Odessa: Astroprint [in Russian].

8. Ivashkin, A. (1994). Conversations with Alfred Shnittke. Moscow: Culture [in Russian].

9. Kierkegaard, S. (2012). Concluding unscientific postscript to Philosophical fragments. (N. Isaieva, S. Isaiev, Trans). Moscow: Akademicheskiy Proekt [in Russian].

10. Craig, E. (1998). Memories, articles, letters. Moscow: Art [in Russian].

11. Curt, P. (2002). Furious dance of life. Moscow: Exmo [in Russian].

12. Maslow, A. (1999). Motivation and personality. St. Petersburg: Eurasia. Retrieved from http://psylib.org.ua/books/masla01/txt00.htm [in Russian].

13. Melik-Pashaev, A. (1998) About a source of human ability to artistic creativity. Questions of psychology, no. 1 [in Russian].

14. Moskalenko, V. (2012). Lectures on musical interpretation. Tutorial. Kiev [in Russian].

15. Maugham, S. (1982). The Moon and Sixpence. Moscow: Truth. Retrieved from http://www.lib.ru/INPROZ/MOEM/moon.txt_with-big-pictures.html

16. Rosental, M. (1972). Philosophical dictionary. Moscow: Political publishing house [in Russian].

17. Samoilenko, A. (2009). Spirituality as a category of musical semantics. Scientific bulletin of ONMA by A. V. Nezhdanova, no. 10. Odessa: Publishing House [in Ukrainian].

18. Sokol, A. (2007). Performing notes, image of the world and musical. Odessa: Seaman [in Russian].

19. Stanislavsky, K. (1981). An actor's work. Moscow: Art [in Russian].

20. Sulerzhitsky, L. (1970). Stories and Novellas. Articles and notes about theatre. Correspondence. Moscow: Art [in Russian]. 
21. Fromm, E. (2006). Man for Himself. Moscow: Ast [in Russian].

22. Horuzhenko, K. (1997). Culturology. Encyclopedic dictionary. Rostov-onDon: Feniks [in Russian].

23. Shlifstein, S. (1961). S. S. Prokofiev: materials, documents, memories. Moscow: State musical publishing house [in Russian].

Стаття надійшла до редакції 28.06.2017

УДК 78.03+78.021/78.071.1

\author{
Анна Дмитрівна Стоянова \\ https://orcid.org/0000-0002-3092-1922 \\ здобувач кафедри історії музики \\ та музичної етнографіі \\ Одеської національної музичної \\ академії ім. А. В. Нежданової \\ Flame.reddik@gmail.com \\ Magali57@rambler.ru

\section{ЯВИЩЕ СОЛІЛОКВІУМА У СУЧАСНІЙ КОМПОЗИТОРСЬКІЙ ТВОРЧОСТІ: ДО ПОСТАНОВКИ ПРОБЛЕМИ}

Метою дослідження є розгляд проблеми солілоквіума як форми особливого внутрішнього діалогу у сучасній композиторській творчості, визначення місия $і$ значення солілоквіума в музиці. Методологія статті грунтується на узагальненні досліджень проблеми солілоквіума у мистецтвознавчих роботах. Використовується аналітичний підхід до концепиії внутрішнього мовлення стосовно їі проекції на твори мистецтва, наводиться порівняльна характеристика діалогу та самодіалогу. Наукова новизна обумовлена тим, що в статті вперше здійснюється різнобічна аналітична характеристика явища солілоквіума в різних видах мистеитва, дається розгорнуте визначення місия солілоквіума в музиці. Висновки. Солілоквіум в музиці стає естетичною парадигмою, яка обростає композиційними прийомами, тобто він не локалізуеться в одній жанровій формі, але визначає жанровий спосіб творчості, породжуючи певні композиційні рішення. Музичний солілоквіум формує власну семантичну сферу, пов'язану як з діалогічними прийомами, так $і$ зі стильовою єдністю музичного матеріалу, тобто виступає як еквівалент авторського монодіалогу.

Ключові слова: солілоквіум, самодіалог, види діалогу, внутрішне мовлення, музичний солілоквіум. 